\title{
Pengaruh Penerapan Model Pembelajaran Investigasi Kelompok Terhadap Kemampuan Pemecahan Masalah Matematika Siswa Kelas VIII SMP
}

\author{
Uswatun Hasana $^{1)}$, Nursalam ${ }^{2)}$, Mardhiah ${ }^{3)}$ \\ ${ }^{1,2,3}$ Fakultas Tarbiyah dan Keguruan UIN Alauddin Makassar \\ uswachua46@gmail.com ${ }^{1)}$,nursalam_ftk@uin-alaudin.ac.id ${ }^{2)}$, Dhiah612@gmail.com ${ }^{3)}$
}

\begin{abstract}
Abstrak
Penelitian ini bertujuan untuk mengetahui tingkat kemampuan pemecahan masalah matematika siswa sebelum dan setelah menggunakan model pembelajaran investigasi kelompok serta mengetahui pengaruh penerapan model pembelajaran investigasi kelompok terhadap kemampuan pemecahan masalah matematika siswa kelas VIII SMPN 1 Tarowang Kabupaten Jeneponto. Penelitian ini merupakan jenis penelitian pre-experimental dengan desain one-group pretestposttest design. Teknik analisis data yang digunakan adalah statistik deskriptif dan statistik inferensial. Berdasarkan hasil analisis data deskriptif diperoleh rata-rata nilai kelas eksperimen, yaitu pretest sebesar 34,38 dan posttest sebesar 78,21, dan berdasarkan hasil analisis statistik inferensial diperoleh nilai sig. Sebesar 0,00 yang lebih kecil dari pada $\alpha$ sebesar $0,05($ sign. $<\alpha)$ sehingga disimpulkan bahwa terdapat perbedaan tingkat kemampuan pemecahan masalah matematika antara sebelum dan sesudah menerapkan model pembelajaran investigasi kelompok. Nilai rata-rata yang diperoleh siswa setelah menggunakan pembelajaran investigasi kelompok lebih tinggi dibandingkan dengan nilai rata-rata yang diperoleh sebelum menggunakan model pembelajaran investigasi kelompok. Artinya, model pembelajaran investigasi kelompok berpengaruh terhadap kemampuan pemecahan masalah matematika siswa kelas VIII SMP Negeri 1 Tarowang Kabupaten Jeneponto yang berdasarkan pada hasil analisis inferensial menggunakan uji paired sampel t-test dengan nilai $\mathrm{t}_{\text {hitung }}=58,476>\mathrm{t}_{\mathrm{tab}}=1,701$.
\end{abstract}

Kata Kunci: Pemecahan Masalah, Investigasi Kelompok

\section{Pendahuluan}

Faktor-faktor yang menyebabkan ketidakmampuan siswa memecahkan masalah matematika yang dominan adalah cara mengajar guru. Guru-guru masih mengajar dengan cara lama, dimana guru ataupun peneliti menyampaikan materi dengan metode ceramah, kemudian siswa mencatat materi dan mengerjakan soal-soal rutin. Terbiasanya siswa mengerjakan soal-soal rutin membuat siswa tidak dapat memecahkan suatu masalah apabila diberikan soal-soal yang berbentuk non rutin. Mereka tidak terbiasa untuk memecahkan suatu masalah secara bebas dan mencari solusi penyelesaiannya dengan cara mereka sendiri. Apabila soalnya berbeda mereka mulai kebingungan karena mereka tidak memahami langkah-langkah dalam memecahkan suatu masalah (Andini, 2013). Dalam proses pembelajaran yang baik, pembelajaran tidak hanya terfokus kepada guru saja tapi siswa harus lebih berperan aktif, dimana guru hanya berperan sebagai motivator dan yang dominan aktif adalah siswa. Salah satu pembelajaran yang menuntut keaktifan siswa serta kekompakan siswa adalah pembelajaran kooperatif tipe investigasi kelompok. Model investigasi kelompok ini adalah salah satu metode spesialisasi tugas yang memberikan kesempatan pada siswa untuk mengembangkan kreativitas dan produktivitas berpikir. Siswa dilibatkan sejak perencanaan, baik dalam menentukan topik maupun cara untuk mempelajarinya melalui kegiatan investigasi. Secara umum metode investigasi sebenarnya dapat dipandang sebagai metode belajar "pemecahan masalah" atau metode belajar "penemuan" (Slavin, 2005). Hal ini didukung oleh penelitian-penelitian terkait yang mengemukakan bahwa model pembelajaran investigasi kelompok berpengaruh terhadap kemampuan pemecahan masalah. Hal ini dikarenakan pada tahap-tahap pelaksanaan pembelajaran investigasi kelompok siswa dapat mengembangkan kemampuan pemecahan masalah dimana peserta didik secara rutin diberikan proyek investigasi untuk dipecahkan bersama kelompoknya sehingga siswa belajar memberikan respon terhadap masalah dan menyelesaikan masalah yang diberikan (Andini, 2013). 
Salah satu sekolah yang belum menggunakan model pembelajaran investigasi kelompok adalah SMP Negeri 1 Tarowang. Berdasarkan hasil wawancara peneliti dengan seorang guru mata pelajaran matematika di SMP Negeri 1 Tarowang, kemampuan pemecahan masalah matematika siswa kelas VIII masih rendah. Hal ini dilihat dari data hasil ulangan semester pada mata pelajaran matematika yang sangat jauh dari kategori baik. Peneliti juga melakukan wawancara pada beberapa peserta didik, dan hasilnya menunjukkan bahwa sangat sedikit yang menyukai pelajaran matematika. Mereka menganggap bahwa pelajaran matematika merupakan pelajaran yang sangat sulit dan penuh dengan tantangan. Mereka cenderung mudah menyerah ketika dihadapkan pada perrmasalahanpermasalahan yang sulit pada mata pelajaran matematika. Ditemukan fakta bahwa banyak peserta didik yang kurang dalam memposisikan seberapa bernilai dirinya dimata teman-temannya. Hal itu dapat terlihat dari masih rendahnya rasa percaya diri dari dalam diri peserta didik, seperti mereka masih belum mampu menentukan cita-cita dan target yang mereka inginkan untuk kedepannya, mereka juga masih malu-malu dalam mengeluarkan pendapat, bahkan tidak jarang mereka hanya diam dan mendengarkan. Masalah matematika dibedakan menjadi dua jenis yaitu masalah untuk menemukan dan masalah untuk membuktikan. Pada masalah untuk menemukan, intinya adalah siswa diharapkan menentukan solusi atau jawaban dari masalah. Sementara itu, pada masalah untuk membuktikan, para siswa diharapkan untuk menunjukkan kebenaran dari teorema atau pernyataan. Namun, dalam pembelajaran matematika di sekolah menengah atas (SMA), memecahkan masalah matematika tidak dapat dilakukan dengan cepat dan mudah. Para siswa perlu algoritma berpikir dengan kemampuan berpikir kritis untuk memecahkan masalah (Rasiman, 2015).

Ada empat langkah dalam menyelesaikan masalah yaitu 1) memahami masalah, pada kegiatan ini yang dilakukan adalah merumuskan: apa yang diketahui, apa yang ditanyakan, apakah informasi cukup, kondisi (syarat) apa yang harus dipenuhi, menyatakan kembali masalah asli dalam bentuk yang lebih operasional, 2) merencanakan pemecahannya, kegiatan yang dilakukan pada langkah ini adalah mencoba mencari atau mengingat masalah yang pernah diselesaikan yang memiliki kemiripan dengan sifat yang akan dipecahkan, mencari pola atau aturan, menyusun prosedur penyelesaian, 3) melaksanakan rencana, kegiatan pada langkah ini adalah menjalankan prosedur yang telah dibuat pada langkah sebelumnya untuk mendapatkan penyelesaian, 4) memeriksa kembali prosedur dan hasil penyelesaian, kegiatan pada langkah ini adalah menganalis dan mengevaluasi apakah prosedur yang diterapkan dan hasil yang diperoleh benar, apakah ada prosedur lain yang lebih efektif, apakah prosedur yang dibuat dapat digunakan untuk menyelesaikan masalah sejenis, atau apakah prosedur dapat dibuat generalisasinya (Polya, 1973). Pemecahan masalah adalah proses menerapkan pengetahuan yang telah diperoleh sebelumnya ke dalam situasi baru yang belum dikenal. Dengan demikian ciri dari penugasan berbentuk pemecahan masalah adalah: (1) ada tantangan dalam materi, tugas, atau soal, (2) masalah tidak dapat diselesaikan dengan menggunakan prosedur rutin yang sudah diketahui penjawab (Wardhani, 2006). Berdasarkan uraian diatas, dapat diartikan bahwa dalam pemecahan masalah siswa didorong dan diberi kesempatan seluas-luasnya untuk berinisiatif dan berfikir sistematis dalam menghadapi suatu masalah dengan menerapkan pengetahuan yang didapat sebelumnya. Kemampuan penyelesaian masalah adalah kemampuan menyelesaikan masalah rutin, non-rutin, rutin terapan, rutin non-terapan, non-rutin terapan, dan masalah non-rutin non-terapan dalam bidang matematika. Masalah rutin adalah masalah yang prosedur penyelesaiannya sekadar mengulang secara algoritmik. Masalah non-rutin adalah masalah yang prosedur penyelesaiannya memerlukan perencanaan penyelesaian, tidak sekadar menggunakan rumus, teorema, atau dalil. Masalah rutin terapan adalah masalah yang dikaitkan dengan dunia nyata atau kehidupan sehari-hari. Masalah rutin non-rerapan adalah masalah rutin yang prosedur penyelesaiannya melibatkan berbagai algoritma matematika. Masalah non-rutin terapan adalah masalah yang penyelesaiannya menuntut 
perencanaan dengan mengaitkan dunia nyata atau kehidupan sehari-hari. Masalah non-rutin nonterapan adalah masalah yang hanya berkaitan dengan hubungan matematika semata (Karunia, 2015).

Model investigasi kelompok sering dipandang sebagai model yang paling kompleks dan paling sulit untuk dilaksanakan dalam pembelajaran kooperatif. Model ini melibatkan siswa sejak perencanaan, baik dalam menentukan topik maupun cara untuk mempelajarinya melalui investigasi (Hamdani, 2011). Investigasi kelompok (group investigation) adalah strategi belajar kooperatif yeng menempatkan siswa ke dalam kelompok untuk melakukan investigasi terhadap suatu topik. Dari pernyataan tersebut dapat disimpulkan bahwa metode GI mempunyai fokus utama untuk melakukan investigasi terhadap suatu topik atau objek khusus (Maimunah, 2005). Berdasarkan teori yang telah diuraikan oleh beberapa ahli mengenai model investigasi kelompok, maka penulis menyimpulkan bahwa model investigasi kelompok adalah strategi belajar kooperatif yang dipandang sebagai model yang paling kompleks dan paling sulit untuk dilaksanakan dalam pembelajaran karena model ini melibatkan siswa sejak perencanaan, baik dalam menentukan topik maupun cara untuk mempelajarinya melalui investigasi serta menekankan pada partisipasi dan aktivitas siswa untuk mencari sendiri materi (informasi) pelajaran yang akan dipelajari melalui bahan-bahan yang tersedia misalnya dari buku pelajaran atau siswa dapat mencari melalui internet. Langkah-langkah pembelajaran pada model pembelajaran GI adalah 1) guru membagi kelas menjadi beberapa kelompok yang heterogen, 2) guru menjelaskan maksud pembelajaran dan tugas kelompok yang harus dikerjakan, 3) guru memanggil ketua-ketua kelompok untuk memanggil materi tugas secara kooperatif dalam kelompoknya, 4) masing-masing kelompok membahas materi tugas secara kooperatif dalam kelompoknya, 5) setelah selesai, masing-masing kelompok yang diwakili ketua kelompok atau salah satu anggotanya menyampaikan hasil pembahasannya, 6) kelompok lain dapat memberikan tanggapan terhadap hasil pembahasannya, 7) guru memberikan penjelasan singkat (klarifikasi) bila terjadi kesalahan konsep dan memberikan kesimpulan, 8) evaluasi (Supandi, 2005).

\section{Metode Penelitian}

Pendekatan yang digunakan peneliti adalah pendekatan kuantitatif. Penelitian kuantitatif adalah jenis penelitian yang menghasilkan penemuan-penemuaan yang dapat dicapai (diperoleh) dengan menggunakan prosedur-prosedur statistik atau cara-cara lain dari kualifikasi (pengukuran) (Sujarweni, W, 2014). Jenis penelitian ini adalah jenis penelitian pre-experimental. Penelitian preexperimental belum merupakan eksperimen sungguh-sungguh karena masih terdapat variabel luar yang ikut berpengaruh terhadap terbentuknya variabel dependen. Jadi, hasil eksperimen yang merupakan variabel dependen itu bukan semata-mata dipengaruhi oleh variabel independen. Hal ini dapat terjadi karena tidak adanya variabel kontrol (Sugiyono, 2014). Desain penelitian yang digunakan oleh peneliti adalah one-group pretest-posttest design. Di dalam desain ini terdapat pretest, tes yang digunakan untuk mengetahui kemampuan pemecahan masalah matematika sebelum diberi perlakuan dan posttest yaitu tes yang digunakan untuk mengetahui kemampuan pemecahan masalah matematika setelah diberikan perlakuan. Dengan demikian hasil perlakuan dapat diketahui lebih akurat, karena dapat membandingkan dengan keadaan sebelum diberi perlakuan. (Sugiyono, 2014).

Populasi dalam penelitian ini adalah seluruh siswa kelas VIII SMP Negeri 1 Tarowang Kabupaten Jeneponto yang berjumlah 145 orang yang terdiri dari 5 kelas yaitu kelas $\mathrm{VIII}_{1}, \mathrm{VIII}_{2}, \mathrm{VIII}_{3}$ $\mathrm{VIII}_{4}$ dan $\mathrm{VIII}_{5}$. Dari kelima kelas yang menjadi populasi dilakukan pengundian dan yang terpilih sebagai sampel penelitian adalah kelas VIII $_{2}$ sebagai kelas eksperimen. Teknik pengumpulan data yang digunakan dalam penelitian ini adalah tes untuk mengetahui kemampuan pemecahan masalah 
matematika siswa yaitu pretest dan posttest pada kelas eksperimen. Instrumen yang digunakan adalah pedoman tes kemampuan pemecahan masalah matematika dalam bentuk essai.

\section{Hasil}

Hasil yang diperoleh dari pretest yang diberikan pada siswa di kelas VIII sebelum menggunakan model pembelajaran investigasi kelompok pada proses pembelajaran di kelas $\mathrm{VIII}_{2}$ dapat dilihat pada tabel berikut.

Tabel 1. Deskripsi Hasil Pretest Kemampuan Pemecahan Masalah Matematika

\begin{tabular}{cccccccc}
\hline \multicolumn{7}{c}{ Descriptive Statistics } \\
\hline & N & Range & Min. & Max. & Mean & SD & Variance \\
Nilai Pretest & 29 & 33 & 15 & 48 & 34.38 & 10.503 & 110.315 \\
Valid N (listwise) & 29 & & & & & & \\
\hline
\end{tabular}

Berdasarkan tabel 1, maka dapat diketahui bahwa skor maksimum yang diperoleh pada pretest sebelum menggunakan model pembelajaran investigasi kelompok adalah 48 , sedangkan skor minimum adalah 15. Persentase tiap indikator ditunjukkan melalui tabel berikut.

Tabel 2. Persentase Kontribusi per Indikator terhadap Hasil Pretest Kemampuan Pemecahan Masalah Matematika pada Kelas Eksperimen

\begin{tabular}{llcccc}
\hline $\begin{array}{c}\text { Variabel } \\
\text { penelitian }\end{array}$ & \multicolumn{1}{c}{ Indikator KPM } & $\begin{array}{c}\text { Skor } \\
\text { Siswa }\end{array}$ & $\begin{array}{c}\text { Skor } \\
\text { Ideal }\end{array}$ & $\begin{array}{c}\text { Pencapaian Indikator } \\
(\boldsymbol{\%})\end{array}$ & $\begin{array}{c}\text { Persentase } \\
(\boldsymbol{\%})\end{array}$ \\
\hline \multirow{2}{*}{$\begin{array}{l}\text { Kemampuan } \\
\text { pemecahan }\end{array}$} & $\begin{array}{l}\text { Membuat persoalan } \\
\text { penyelesaian }\end{array}$ & 278 & 290 & 95.86 & 57.00 \\
masalah & Menjalankan rencana & 611 & 986 & 61.97 & 36.85 \\
matematika & 108 & 1044 & 10.34 & 6.15 \\
& $\begin{array}{l}\text { Melihat kembali apa } \\
\text { yang telah dilakukan }\end{array}$ & 0 & 580 & 0 & 0 \\
& Jumlah & 997 & 2900 & 168.17 & 100 \\
\hline
\end{tabular}

Hasil persentase di atas, dapat diketahui bahwa kontribusi tertinggi berada pada indikator memahami persoalan dengan persentase sebesar 57,00\%. Hal ini menunjukkan bahwa indikator memahami persoalan dapat dipahami dengan baik oleh siswa dalam meningkatkan kemampuan pemecahan masalah matematika.

Tabel 3. Kategori Hasil Pretest Kemampuan Pemecahan Masalah Matematika Kelas Eksperimen

\begin{tabular}{|c|c|c|c|}
\hline \multirow{2}{*}{ Penguasaan } & \multirow[t]{2}{*}{ Kategori } & \multicolumn{2}{|c|}{ Pretest } \\
\hline & & Frekuensi & Persentase (\%) \\
\hline $0-20$ & Sangat rendah & 3 & 10,3 \\
\hline $21-40$ & Rendah & 14 & 48,3 \\
\hline $41-60$ & Sedang & 12 & 41,4 \\
\hline $61-80$ & Tinggi & 0 & 0 \\
\hline $81-100$ & Sangat tinggi & 0 & 0 \\
\hline \multicolumn{2}{|c|}{ Jumlah } & 29 & 100 \\
\hline
\end{tabular}


Kemampuan pemecahan masalah matematika sesuai tabel 3 bahwa untuk pretest pada kelas eksperimen terdapat 3 siswa $(10,3 \%)$ berada pada kategori sangat rendah, 14 siswa $(48,3 \%)$ berada pada kategori rendah, 12 siswa $(41,4 \%)$ berada pada kategori sedang, dan tidak ada siswa berada pada kategori tinggi dan sangat tinggi. Jadi, dapat disimpulkan bahwa persentase terbesar kemampuan pemecahan masalah matematika siswa pretest pada kelas eksperimen berada pada kategori rendah.

Tabel 4. Deskripsi Hasil Posttest Kemampuan Pemecahan Masalah Matematika

\begin{tabular}{cccccccc}
\hline \multicolumn{7}{c}{ Descriptive Statistics } \\
\hline N & Range & Minimum & Max & Mean & SD & Variance \\
\hline Nilai PostTest & 29 & 30 & 60 & 90 & 78.21 & 7.993 & 63.884 \\
\hline Valid N (listwise) & 29 & \multicolumn{1}{c}{ (lisw } & & & & \\
\hline
\end{tabular}

Dilihat dari tabel 4, maka dapat diketahui bahwa skor maksimum yang diperoleh pada posstest setelah menggunakan model pembelajaran investigasi kelompok adalah 90, sedangkan skor minimum adalah 60. Persentase tiap indikator terhadap kemampuan pemecahan masalah matematika dapat ditunjukkan melalui tabel berikut.

Tabel 5. Persentase Kontribusi per Indikator terhadap Hasil Posttest Kemampuan Pemecahan Masalah Matematika pada Kelas Eksperimen

\begin{tabular}{|c|c|c|c|c|c|}
\hline $\begin{array}{c}\text { Variabel } \\
\text { penelitian }\end{array}$ & Indikator KPM & $\begin{array}{l}\text { Skor } \\
\text { Siswa }\end{array}$ & $\begin{array}{l}\text { Skor } \\
\text { Ideal }\end{array}$ & $\begin{array}{c}\text { Pencapaian } \\
\text { Indikator }(\%)\end{array}$ & $\begin{array}{c}\text { Persentase } \\
\text { Indikator (\%) }\end{array}$ \\
\hline \multirow{5}{*}{$\begin{array}{l}\text { Kemampuan } \\
\text { pemecahan } \\
\text { masalah } \\
\text { matematika }\end{array}$} & Memahami persoalan & 290 & 290 & 100 & 33.10 \\
\hline & $\begin{array}{ll}\text { Membuat rencana } \\
\text { penyelesaian }\end{array}$ & 1179 & 1189 & 99.16 & 32.82 \\
\hline & Menjalankan rencana & 624 & 899 & 69.41 & 22.98 \\
\hline & $\begin{array}{l}\text { Melihat kembali apa } \\
\text { yang telah dilakukan }\end{array}$ & 175 & 522 & 34 & 11 \\
\hline & Jumlah & 2268 & 2900 & 302.09 & 100 \\
\hline
\end{tabular}

Hasil persentase di atas, dapat diketahui bahwa kontribusi tertinggi berada pada indikator memahami persoalan dengan persentase sebesar 33,10\%. Hal ini menunjukkan bahwa indikator memahami persoalan dapat dipahami dengan baik oleh siswa dalam meningkatkan kemampuan pemecahan masalah matematika. Jika kemampuan pemecahan masalah matematika siswa dijelaskan dalam kategori sangat rendah, rendah, sedang, tinggi, dan sangat tinggi akan diperoleh frekuensi dan persentase setelah dilakukan posttest maka diperoleh hasil sebagai berikut:

Tabel 6. Kategori Hasil Posttest Kemampuan Pemecahan Masalah Matematika Kelas Eksperimen

\begin{tabular}{llcc}
\hline \multirow{2}{*}{$\begin{array}{c}\text { Tingkat } \\
\text { Penguasaan }\end{array}$} & \multicolumn{1}{c}{ Kategori } & \multicolumn{2}{c}{ Posttest } \\
\cline { 3 - 4 } & & Frekuensi & Persentase (\%) \\
\hline $0-20$ & Sangat rendah & 0 & 0 \\
$21-40$ & Rendah & 0 & 0 \\
$41-60$ & Sedang & 1 & 3,4 \\
$61-80$ & Tinggi & 14 & 48,3 \\
$81-100$ & Sangat tinggi & 14 & 48,3 \\
\hline \multicolumn{2}{c}{} \\
\hline
\end{tabular}


Berdasarkan hasil belajar posttest pada tabel 6, dapat dilihat bahwa pada kelas eksperimen tidak terdapat nilai siswa pada kategori sangat rendah dan rendah, 1 siswa $(3,4 \%)$ pada kategori sedang, 14 siswa $(48,3 \%)$ berada pada kategori tinggi, dan 14 siswa $(48,3 \%)$ berada pada kategori sangat tinggi. Jadi, dapat disimpulkan bahwa persentase terbesar hasil posttest kemampuan pemecahan masalah matematika siswa berada pada kategori tinggi dan sangat tinggi.

Untuk melihat apakah ada perbedaan signifikan pada kemampuan pemecahan masalah matematika siswa sebelum dan setelah diajar dengan menggunakan model pembelajaran investigasi kelompok dalam pembelajaran, analisis yang digunakan adalah analisis statistik inferensial. Sebelum melakukan analisis statistik inferensial, terlebih dahulu dilakukan uji normalitas data hasil pretest dan posttest, dan pengujian hipotesis digunakan uji paired sampel t-test. Berikut hasil pengolahan data dengan tahap yang dimaksud.

Tabel 7. Hasil Uji Hipotesis Paired Samples Correlations

\begin{tabular}{lcccc}
\hline \multicolumn{5}{c}{ Paired Samples Correlations } \\
\hline & N & Correlation & Sig. \\
\hline Pair 1 & Nilai Pretest \& Nilai Posttest & 29 & .941 & .000 \\
\hline
\end{tabular}

Hasil pengolahan dengan menggunakan SPSS versi 20 dengan teknik pengujian paired samples test sesuai pada tabel 7, menunjukkan korelasi antara dua variabel, sehinggs diperoleh angka 0,941 dengan nilai signifikansi $(\mathrm{p})=0,000<0,05$. Artinya korelasi nilai pretest dan posttest adalah berhubungan secara nyata.

Tabel 8. Hasil Uji Hipotesis Paired Samples Test

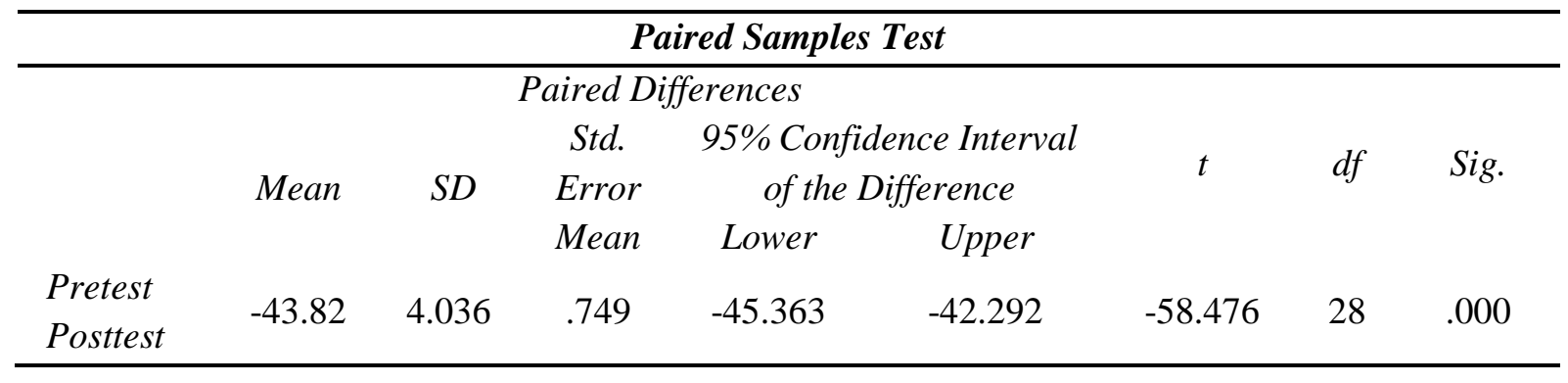

Selanjutnya pada tabel 8 , hasil analisis menggunakan taraf signifikansi $5 \%$ atau 0,05 dan dengan derajat kebebasan $=28$, diperoleh nilai sig. $(2$-tailed $)=0,000$ dan nilai $t_{\text {tabel }}=1,701$. Karena nilai sig. $(2$-tailed $)=0,000<0,05$ atau $\mathrm{t}_{\text {hitung }}=58,476>1,701$ maka Ho ditolak dan $\mathrm{H}_{1}$ diterima. Artinya ada perbedaan rata-rata kemampuan pemecahan masalah matematika yang signifikan sebelum dan sesudah pembelajaran dengan menggunakan model pembelajaran investigasi kelompok pada siswa kelas VIII SMP Negeri 1 Tarowang Kabupaten Jeneponto.

\section{Pembahasan}

Pada penelitian ini, diperoleh hasil bahwa terdapat perbedaan kemampuan pemecahan masalah matematika yang diajar setelah menggunakan model pembelajaran investigasi kelompok dibandingkan dengan yang diajar sebelum menggunakan model pembelajaran investigasi kelompok. Pada kelas eksperimen tersebut, terlihat jelas bahwa pada pretest, nilai yang diperoleh siswa hanya berada pada kategori sangat rendah, rendah dan sedang, sedangkan pada hasil posttest terjadi peningkatan yang cukup maksimal pada kategori tinggi dan sangat tinggi. Dengan demikian, dapat disimpulkan bahwa penerapan model pembelajaran investigasi kelompok berpengaruh positif dan baik digunakan dalam meningkatkan kemampuan pemecahan masalah matematika siswa kelas VIII 
SMP Negeri 1 Tarowang Kabupaten Jeneponto. Kemampuan pemecahan masalah matematika siswa sebelum menggunakan model pembelajaran investigasi kelompok dapat kita lihat secara deskriptif pada hasil penelitian bahwa kemampuan pemecahan masalah matematika siswa masih rendah disebabkan oleh proses pembelajaran selama ini hanya berpusat pada guru sementara siswa pasif dan hanya mendengarkan penjelasan dari guru. Siswa belum dilibatkan secara aktif sehingga guru sulit untuk mengembangkan atau meningkatkan pembelajaran yang benar-benar berkualitas.

Kemampuan pemecahan masalah matematika siswa setelah menggunakan model pembelajaran investigasi kelompok dapat kita lihat secara deskriptif pada hasil penelitian bahwa kemampuan pemecahan masalah matematika siswa berada pada kategori tinggi dan sangat tinggi. Hal ini disebabkan model pembelajaran yang digunakan mampu membuat siswa benar-benar ikut berpartisipasi dalam pembelajaran dengan penggunaan aktivitas yang terus-menerus, mendorong siswa untuk berpikir dan menjelaskan penalaran mereka, sehingga pembelajaran lebih bermakna, dimana siswa tidak sekedar menghafal rumus, akan tetapi siswa dapat menemukan sendiri, bekerja sama agar dapat menerapkan dalam kehidupan, dapat mentransfer dalam bentuk baru sehingga siswa menjadi aktif dalam pembelajaran dan dapat mengkonstruksi sendiri pengetahuannya dengan melibatkan masalah dalam kehidupan sehari-hari. Seiring dengan bertambahnya pertemuan, siswa juga semakin aktif dalam bertanya maupun dalam pembahasan soal, dan siswa yang melakukan aktivitas lain saat pembelajaran semakin berkurang dan kemampuan mengerjakan soal-soal juga meningkat.

Berdasarkan hasil uji hipotesis dengan menggunakan paired sampel t test, diperoleh bahwa H0 ditolak dan H1 diterima yang berarti terdapat perbedaan nilai rata-rata matematika siswa kelas VIII SMP Negeri 1 Tarowang Kabupaten Jeneponto antara sebelum dan sesudah menggunakan model pembelajaran investigasi kelompok. Nilai rata-rata yang diperoleh siswa setelah menggunakan pembelajaran investigasi kelompok lebih tinggi dibandingkan dengan nilai rata-rata yang diperoleh sebelum menggunakan model pembelajaran investigasi kelompok. Artinya model pembelajaran investigasi kelompok berpengaruh terhadap kemampuan pemecahan masalah matematika siswa kelas VIII SMP N 1 Tarowang. Hal ini dikarenakan dalam pembelajaran siswa benar-benar ikut aktif dalam pembelajaran, karena model ini menuntut siswa untuk berpikir kritis, sistematis, kreatif, dan rasional dalam menemukan konsep-konsep atau dalam memecahkan permasalahan yang diberikan. Selain itu, untuk menarik minat siswa dalam memahami konsep-konsep yang tercakup dalam pembelajaran tidaklah mudah. Guru dituntut mampu memiliki dan menggunakan media pembelajaran sesuai dengan materi yang akan disajikan, dituntut mampu menggunakan model pembelajaran secara stimulus untuk menghidupkan suasana pengajaran dengan baik. Pemilihan model belajar yang tepat akan membantu siswa menumbuhkan minat yang ada dalam dirinya sehingga meningkatkan rasa senang, perhatian, kemauan dan kesadaran belajar.

Penelitian ini juga didukung oleh beberapa penelitian sebelumnya, salah satunya penelitian yang dilakukan oleh Meiliana. Berdasarkan hasil penelitian tersebut diperoleh bahwa nilai siswa sebelum dan sesudah pembelajaran dengan model investigasi kelompok mengalami peningkatan kemampuan berpikir kreatif siswa. Hal ini menunjukkan bahwa siswa dengan pembelajaran model investigasi kelompok memberikan perolehan hasil yang lebih baik dalam kemampuan berpikir kreatif matematik daripada siswa yang pembelajarannya secara konvensional. Berdasarkan penjelasan diatas dan penelitian terdahulu yang relevan. Hal ini berarti mendukung diterimanya hipotesis yaitu model pembelajaran investigasi kelompok berpengaruh positif dan cocok digunakan dalam upaya 
meningkatkan kemampuan pemecahan masalah matematika siswa kelas VIII SMP Negeri 1 Tarowang Kabupaten Jeneponto.

\section{Kesimpulan}

Berdasarkan hasil penelitian dan pembahasan pada penelitian ini, maka diperoleh beberapa kesimpulan 1) Kemampuan pemecahan masalah matematika siswa kelas $\mathrm{VIII}_{2}$ sebelum menggunakan model pembelajaran investigasi kelompok memiliki persentase sebesar 10,3\% berada pada kategori sangat rendah, 48,3\% berada pada kategori rendah dan 41,4\% berada pada kategori sedang dengan nilai rata-rata yang diperoleh sebesar 34,38. 2) Kemampuan pemecahan masalah matematika siswa kelas VIII $_{2}$ setelah menggunakan model pembelajaran investigasi kelompok memiliki persentase sebesar 3,4\% berada pada kategori sedang, $48,3 \%$ berada pada kategori tinggi dan 48,3\% berada pada kategori sangat tinggi dengan nilai rata-rata yang diperoleh sebesar 78,21. 3) Terdapat perbedaan nilai rata-rata matematika siswa kelas VIII SMP Negeri 1 Tarowang Kabupaten Jeneponto antara sebelum dan sesudah menggunakan model pembelajaran investigasi kelompok. Nilai rata-rata yang diperoleh siswa setelah menggunakan pembelajaran investigasi kelompok lebih tinggi dibandingkan dengan nilai rata-rata yang diperoleh sebelum menggunakan model pembelajaran investigasi kelompok. Artinya model pembelajaran investigasi kelompok berpengaruh terhadap kemampuan pemecahan masalah matematika siswa kelas VIII SMP Negeri 1 Tarowang Kabupaten Jeneponto yang berdasarkan pada hasil analisis inferensial pada uji hipotesis dengan menggunakan paired sampel t test dengan nilai $\mathrm{t}_{\text {hitung }}=58,476>\mathrm{t}_{\mathrm{tab}}=1,701$.

\section{Daftar Pustaka}

Andini, F. (2013). Pengaruh Model Pembelajaran Investigasi Kelompok Terhadap Kemampuan Pemecahan Masalah Matematika Siswa.

Hamdani. (2011). strategi belajar mengajar. Bandung: CV Pustaka Setia.

Karunia, M. (2015). Penelitian Pendidikan Matematika (I). Bandung: PT Refika Aditama.

Maimunah. (2005). Pembelajaran Volume Bola dengan Belajar Kooperatif Model GI pada Siswa Kelas X SMA Laboratorium UM. Pascasarjana Universitas Negeri Malang, Malang.

Polya. (1973). How To Solve It. New Jersey: Princeton University Press.

Rasiman. (2015). Leveling of Students' Critical Ability in Solving Mathematics Problem Based on Gender Differences. International Journal of Education and Research, 3(4).

Robert Slavin. (2005). Cooperative learning teori riset dan praktik. Bandung: PT Nusa Media.

Sugiyono. (2014). Metode Penelitian Kuantitatif Kualitatif dan $R \& D$ (XX). Bandung: Alfabeta.

Sujarweni, W. (2014). Metodologi Penelitian. Yogyakarta: Pustaka Baru.

Supandi. (2005). Penerapan Pembelajaran Kooperatif dengan Metode GI untuk Meningkatkan Aktivitas dan Hasil Belajar Matematika Siswa Kelas X SMAN 2 Trawas Mojokerto. Universitas Negeri Malang, Malang.

Wardhani. (2006). Permasalahan Pembelajaran dan Penilaian Kemahiran Matematika SMP. Yogyakarta: PPPG Matematika. 